\title{
Pengujian Hidrofobisitas dan Aktivitas Antibiotik terhadap Staphylococcus aureus Isolat Preputium Sapi Aceh
}

\author{
Maryulia Dewi $^{\left.1^{*}\right)}$, Darmawi ${ }^{1}$, T. Zahrial Helmi ${ }^{2}$ \\ ${ }^{1}$ Laboratorium Mikrobiologi Fakultas Kedokteran Hewan, Universitas Syiah Kuala \\ ${ }^{2}$ Laboratorium Biokimia Fakultas Kedokteran Hewan, Universitas Syiah Kuala \\ ${ }^{*}$ Email: maryuliad@gmail.com
}

\begin{abstract}
Abstrak
Penelitian ini bertujuan untuk mengkarakterisasi dan mengamati aktivitas antibiotik terhadap hidrofobisitas Stapylococcus aureus isolat preputium sapi Aceh menggunakan hidrokarbon xylol dan pembaca ELLISA. Hidrofobisitas permukaan berbagai sel mikroba ditentukan dengan mengukur kemampuan penempelan sel terhadap berbagai polimer atau afinitas bakteri terhadap pelarut hidrokarbon. Pengujian hidrofobisitas bakteri dilakukan pada media nutrien cair dengan modifikasi hidrokarbon xylol, menggunakan mikroplat U-bottom polystyrene 96 wells. Antibiotik yang digunakan adalah tetrasiklin, oksitetrasiklin dan fosfomisin dengan konsentrasi masing-masing $10 \%$, $20 \%$ dan $30 \%(\mathrm{mg} / \mathrm{mL})$. OD hidrofobisitas dibaca pada $\lambda 600 \mathrm{~nm}$ menggunakan pembaca ELISSA. Data hasil penelitian di analisis menggunakan analysis of variance (ANOVA). Hasil penelitian menunjukkan aktivitas virulensi Staphylococcus aureus isolat preputium sapi Aceh berdasarkan karaksteristik hidrofobisitas tergolong positif moderat, yaitu $36,76 \%$. Perlakuan antibiotik berpengaruh secara nyata $(\mathrm{P}<0,05)$ terhadap daya hidrofobisitas, sedangkan konsentrasi tidak berpengaruh secara nyata $(\mathrm{p}<0,05)$ terhadap daya hidrofobisitas Staphylococcus aureus isolat preputium sapi Aceh. Tetrasiklin $30 \%(\mathrm{mg} / \mathrm{mL})$ mempunyai kemampuan paling baik meningkatkan hidrofobisitas Staphylococcus aureus isolat preputium sapi Aceh sebesar 36,16\% menjadi 72,29\%, sehingga aktivitas virulensi Staphylococcus aureus isolat preputium sapi Aceh berdasarkan karaksteristik hidrofobisitas dari positif moderat menjadi positif palsu.
\end{abstract}

Kata Kunci: hidrofobisitas, antibiotik, pembaca ELISSA, xylol, Staphylococcus aureus.

\begin{abstract}
This study aims to characterize and observe the antibiotic activity of the hydrophobicity of Stapylococcus aureus in prepuce isolates of Aceh cow by using xylol hydrocarbons and ELLISA readers. The surface hydrophobicity of various microbial cells were determined by measuring the ability of cell attachment to various polymers or bacterial affinity to hydrocarbon solvents. Testing of bacterial hydrophobicity was carried out on liquid nutrient media with modification of xylol hydrocarbons, using 96 wells U-bottom polystyrene microplates. The antibiotics used were tetracycline, oxytetracycline and phosphomycin with concentrations of 10\%, 20\% and $30 \%$ ( $\mathrm{mg} / \mathrm{mL}$, respectively). The hydrophobicity $O D$ was detected at $\lambda 600 \mathrm{~nm}$ using the ELISSA reader. The results of the research data were analyzed using analysis of variance (ANOVA). The results showed the virulence activity of Staphylococcus aureus of Aceh cow prepuce isolates based on the characteristics of hydrophobicity was categorized as moderate, i.e. $36.76 \%$. Antibiotic treatment had a significant effect $(P<0.05)$ on hydrophobicity, while the concentration had no significant effect $(p<0.05)$ on the hydrophobicity of Staphylococcus aureus in Aceh cow prepuce isolates. Tetracycline $30 \%$ ( $m g$ $1 \mathrm{~mL}$ ) had the best ability to increase the hydrophobicity of Staphylococcus aureus Aceh cow prepuce isolate by $36.16 \%$ to $72.29 \%$, so that the virulence activity of Staphylococcus aureus Aceh prepuce preparations based on the characteristics of hydrophobicity from positive to moderate to false positive.
\end{abstract}

Keyword: hydrophobicity, antibiotics, ELISSA readers, xylol, Staphylococcus aureus.

\section{Pendahuluan}

Seiring dengan berkembangnya penemuan dibidang biologi molekuler, banyak metode yang telah dikembangkan untuk menentukan jalur patogenik suatu bakteri. Namun masih banyak metode konvesional yang dapat digunakan untuk menentukan jalur patogenik bakteri seperti pengujian terhadap hidrofobisitas bakteri. Hidrofobisitas merupakan salah satu aktivitas virulensi bakteri yang dapat menentukan jalur patogenisitas suatu bakteri (Das dan Kapoor, 2004).

Sifat hidrofobisitas pada bakteri tergantung dari komponen permukaan sel bakteri yang mempengaruhi perlekatan (adhesi) bakteri pada permukaan sel inang. Mekanisme adhesi Staphylococcus aureus (S. aureus) pada mukosa 
host dimulai dari invasi dan melekat pada jaringan host, invasi ke jaringan host, multiplikasi dan kolonisasi pada jaringan, menghindar dari sistem imun host dan merusak jaringan serta resistensi terhadap antibiotik. Adhesi bakteri yang diikuti dengan terjadinya kolonisasi pada host adalah tanda mulai terjadinya patogenesis penyakit (Jawetz et al., 2005). Bakteri yang mempunyai kemampuan adhesi dan kolonisasi serta pertahanan terhadap fagositosis lebih bersifat virulen dari bakteri umumnya (Lestari dan Siti, 2015).

Hidrofobisitas permukaan berbagai sel mikroba dapat ditentukan dengan mengukur kemampuan penempelan sel terhadap berbagai polimer, atau afinitas bakteri terhadap pelarut hidrokarbon dalam sistem 2 fase yaitu daya lekat dan pertumbuhan pada hidrokarbon (Rosenberg dan Doyle, 1990). Menurut Lee dan Yii, 1996, uji hidrofobisitas bakteri dapat dilakukan dengan berbagai cara diantaranya: menggunakan presipitasi permukaan sel dengan garam, membran nitroselulosa, kromatografi kolom dan interaksi bakteri terhadap hidrokarbon yang menggunakan n-heksan atau n-oktana dalam tabung asam. Dalam penelitian ini pelarut yang digunakan adalah xylol karena lebih ekonomis dan lebih mudah didapatkan. Pengukuran OD (optical density) dilakukan menggunakan alat pembaca ELLISA karena lebih akurat dan tidak dipengaruhi oleh intensitas warna seperti pada pengukuran menggunakan alat Spektrofotometri.

Perubahan hidrofobisitas pada bakteri dapat terjadi selama proses morfogenesis dan adanya senyawa yang bersifat antimikroba. Penambahan umur bakteri juga dapat meningkatkan sifat hidrofobik. Antibiotik dapat menurunkan atau meningkatkan hidrofobisitas bakteri tergantung dari spesies bakteri dan senyawa antibiotik (Rosenberg dan Doyle, 1990). Penelitian ini bertujuan untuk mengukur sifat hidrofobisitas S. aureus isolat sapi Aceh terhadap pelarut xylol, dan melihat aktivitas antibiotik terhadap sifat hidrofobisitas S. aureus isolat sapi Aceh.

\section{Metode Penelitian}

Penentuan hidrofobisitas bakteri dilakukan dengan modifikasi metode BATH pada hidrokarbon xylol, dengan cara Lee dan Yii (1996) sebagai berikut: sebanyak 4,8 mL suspensi bakteri $S$. aureus yang mengandung $10^{6} \mathrm{cfu} / \mathrm{mL}$ disentrifus pada $1900 \mathrm{rpm}$ selama 15 menit. Supernatan kultur dibuang dan pelet bakteri ditambah 4,8 mL Nutrient Broth (NB) yang mengandung antibiotik tetrasiklin, oksitetrasiklin dan fosfomisin dengan konsentrasi 10, 20 dan $30 \mathrm{mg} / \mathrm{mL}$. Kontrol hidrofobisitas digunakan penambahan $1,07 \mathrm{ml}$ bufer fosfat dan $3,73 \mathrm{ml}$ media NB pada pelet bakteri, sehingga volume akhir menjadi $4,8 \mathrm{~mL}$. Selanjutnya suspensi bakteri tersebut diinkubasi pada suhu $37^{\circ} \mathrm{C}$ selama 30 menit. Kultur bakteri dipisahkan dengan cara sentrifus pada $1900 \mathrm{rpm}$ selama 15 menit. Pelet yang terbentuk dicuci satu kali dengan Phospat Buffer Saline (PBS) pH 7.2 steril, diresuspensikan dalam PBS menjadi 4,8 mL. Setiap 4,8 mL suspensi bakteri $10^{6} \mathrm{cfu} / \mathrm{mL}$ ditambahkan pada seri volume hidrokarbon $1 \mathrm{~mL}$ xylol dalam tabung yang tahan asam. Kemudian divortex dengan kecepatan konstan selama satu menit, dan diekuilibrasi pada suhu kamar selama 15 menit, sehingga terjadi pemisahan. Fase air diambil secara perlahan-lahan menggunakan pipet Pasteur dan sebanyak $200 \mu \mathrm{L}$ fase air dipindahkan ke mikroplat kemudian absorbansi diukur pada A $600 \mathrm{~nm}$. Hidrofobisitas ditentukan berdasarkan persentase OD (optical density), pada fase air, menggunakan pembaca ELISSA.

Persen hidrofobisitas $=100-(\mathrm{A} \times 100 / \mathrm{Ao})$, dimana A adalah OD dari suspensi bakteri pada fase air setelah kontak dengan xylol dan Ao merupakan OD suspensi tanpa penambahan xylol yang mempunyai nilai hidrofobisitas setara dengan 0 persen. Perubahan adsorban tingkat hidrophobisitas berhubungan dengan kemampuan bakteri $S$. aureus meningkatkan virulensi pada proses adhesin protein permukaan host.

\section{Hasil dan Pembahasan}

Sifat hidrofobitas permukaan S. aureus isolat preputium sapi Aceh yang diperoleh dari pengukuran OD pada pembaca ELISSA setelah kontak dengan xylol adalah 36,76\%, hal ini menunjukkan bahwa aktivitas virulensi bakteri tersebut masuk dalam kategori positif moderat. Hasil ini merujuk pada karakteristik hidrofobisitas bakteri metode Bath berdasarkan kriteria Das dan Kapoor, (2004) yaitu < 25\% artinya negatif, $25 \%-70 \%$ positif moderat dan $>70 \%$ positif kuat. Sifat hidrofobisitas bakteri ditentukan oleh struktur molekul pada permukaan sel bakteri yang berperan dalam proses adhesi pada sel epitel inang. Perlekatan $S$. aureus pada permukaan mukosa host diperantarai oleh protein permukaan sel dan kesatuan dinding sel yang dapat meningkatkan adhesi. Adhesi protein fimbrie bersifat hidrofobik karena jumlah asam amino 
hidrofobik penyusun protein fimbrie dan struktur tersier protein. Sifat hidrofobik fimbrie ini akan meningkatkan afinitas bakteri pada reseptor, sehingga terjadi pelekatan bakteri pada reseptor permukaan sel epitel. Sifat hidrophobisitas ini memungkinkan bakteri tetap tinggal dipermukaan mukosa dan berkembang biak atau berpenetrasi kedalam jaringan (Plata, 2009).

Persentase aktivitas antibiotik terhadap daya hidrofobisitas $S$. aureus dapat dilihat pada Gambar 1.

Persentase aktivitas antibiotik terhadap daya hidrofobisitas S. aureus, pada penggunaan tetrasiklin, oksitetrasiklin dan fosfomisin dari Gambar 1 terlihat terjadi peningkatan daya hidrofobisitas seiring meningkatnya konsentrasi. Hasil tertinggi terdapat pada aktivitas tetrasiklin $30 \%$ yaitu sebesar $72,29 \%$ dan terendah pada fosfomisin konsentrasi $10 \%$ yaitu sebesar 22,52\%. Hasil uji ANOVA menunjukkan aktivitas antibiotik terhadap daya hidrofobisitas S. aureus berdasarkan jenis antibiotik berbeda sangat nyata $(\mathrm{p}<0,05)$ antar perlakuan. Selanjutnya hasil uji Duncan menunjukkan aktivititas hidrofobisitas tetrasiklin berbeda dengan oksitetrasiklin dan berbeda juga dengan aktivitas fosfomisin. Berdasakan konsentrasi antibiotik tidak berbeda nyata $(\mathrm{p}<0,05)$ pada perlakuan konsentrasi 10\%, 20\% dan $30 \%$.

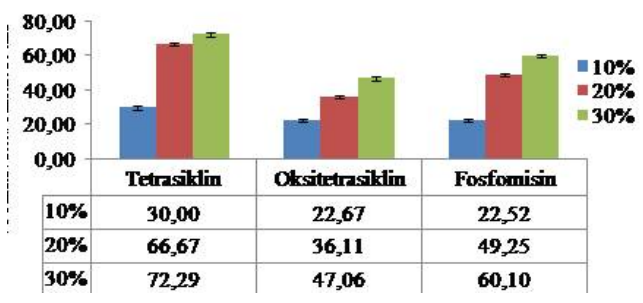

Gambar 1.

Aktivitas antibiotik tetrasiklin, oksitetrasiklin dan fosfornisin terhadap daya hidrofobisitas $S$. Aureus.

Bakteri yang bersifat hidrofobik, permukaan selnya tersusun dari molekul-molekul protein dan saat melekat pada sel epitel akan mudah difagosit oleh sel-sel polimorfonuklear (Salasia et al., 2005). Hasil penelitian menunjukkan bahwa tetrasiklin 30\% mampu meningkatkan hidrofobisitas $S$. aureus isolat preputium sapi Aceh dari $36,76 \%$ menjadi $72,29 \%$ sehingga bakteri bersifat hidrofobik kuat. Perubahan sifat hidrofobisitas pada $\quad S$. aureus menunjukkan adanya perubahan struktur permukaan sel bakteri yang mengakibatkan perubahan sistem enzim yang mengkoordinir produksi protein ekstraseluler. Keseluruhan peristiwa ini merupakan salah satu mekanisme penghambatan pertumbuhan dan virulensi bakteri (Fardiaz dan Radiati, 2012).

Antimikroba dapat menurunkan atau meningkatkan sifat hidrofobisitas permukaan bakteri tergantung dari spesies bakteri dan senyawa antimikroba yang digunakan. Kemampuan antibiotik meningkatkan dan menurunkan hidrofobisitas $S$. aureus dapat dilihat berdasarkan daya hidrofobisitas relatif. Persentase daya hidrofobisitas relatif dapat dilihat pada Gambar 2.

Persentase daya hidrofobisitas relatif antibiotik terhadap S. aureus, dari Gambar 2 terlihat bahwa masing-masing antibiotik mempunyai kemampuan meningkatkan dan menurunkan hidrofobisitas $S$. aureus. Tetrasiklin mempunyai kemampuan paling tinggi dalam meningkatkan hidrofobisitas $S$. aureus yaitu sebesar $36,16 \%$ dan terendah oksitetrasiklin $30 \%$ yaitu $11,00 \%$. Hasil uji ANOVA menunjukkan aktivitas antibiotik terhadap daya hidrofobisitas relatif berdasarkan jenis antibiotik berbeda sangat nyata $(p<0,01)$ antar perlakuan. Selanjutnya hasil uji Duncan menunjukkan aktivititas tetrasiklin berbeda dengan oksitetrasiklin dan fosfomisin. Berdasakan konsentrasi tidak berbeda nyata $(\mathrm{p}<0,05)$ antara perlakuan konsentrasi $10 \%$, $20 \%$ dan $30 \%$.

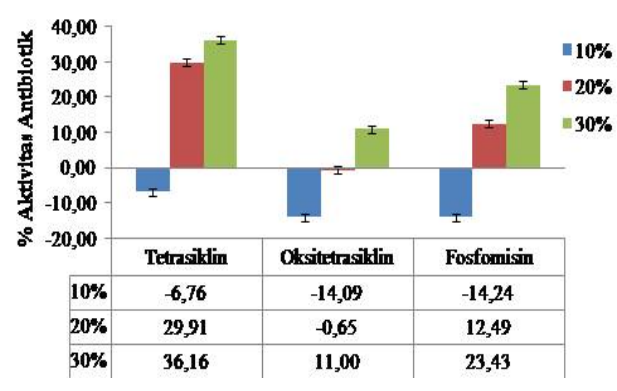

Gambar 2.

Aktivitas antibiotik tetrasiklin, oksitetrasiklin dan fosfornisin terhadap daya hidrofobisitas relatif $S$. aureus

Persentase daya hidrofobisitas relatif antibiotik terhadap $S$. aureus, dari Gambar 2 terlihat bahwa masing-masing antibiotik mempunyai kemampuan meningkatkan dan menurunkan hidrofobisitas $S$. aureus. Tetrasiklin mempunyai kemampuan paling tinggi dalam meningkatkan hidrofobisitas $S$. aureus yaitu sebesar $36,16 \%$ dan terendah oksitetrasiklin $30 \%$ yaitu $11,00 \%$. Hasil uji ANOVA menunjukkan aktivitas antibiotik terhadap daya hidrofobisitas relatif berdasarkan 
jenis antibiotik berbeda sangat nyata $(\mathrm{p}<0,01)$ antar perlakuan. Selanjutnya hasil uji Duncan menunjukkan aktivititas tetrasiklin berbeda dengan oksitetrasiklin dan fosfomisin. Berdasakan konsentrasi tidak berbeda nyata $(\mathrm{p}<0,05)$ antara perlakuan konsentrasi $10 \%$, $20 \%$ dan $30 \%$.

Hasil penelitian menunjukkan bahwa tetrasiklin dan fosfomisin konsentrasi $10 \%$, serta oksitetrasiklin konsentarsi $10 \%$ dan $20 \%$ bersifat menurunkan hidrofobisitas S. aureus isolat preputium sapi Aceh. Penurunan hidrofobisitas pada $S$. aureus kemungkinan disebabkan oleh senyawa peptida berinteraksi dengan fimbriae dan mengakibatkan penggumpalan protein, sehingga protein ini kehilangan struktur hidrofobiknya dan mengakibatkan hidrofobisitas bakteri menurun (Rosenberg dan Doyle, 1990). Tetrasiklin dan fosfomisin mampu meningkatkan hidrofobisitas $S$. aureus isolat preputium sapi Aceh mulai dari konsentrasi $20 \%$ dan 30\%, sedangkan oksitetrasiklin baru mampu meningkatkan hidrofobisitas S. aureus isolat preputium sapi Aceh mulai dari konsentrasi $30 \%$. Peningkatan hidrofobisitas pada $S$. aureus, kemungkinan disebabkan oleh terekstraksinya komponen terluar sel yang bersifat hidrofilik, sehingga yang menonjol adalah LPS yang meningkatkan hidrofobisitas bakteri. Dengan adanya perlakuan antibakteri akan mengakibatkan perubahan kapsul bakteri yang simetris sehingga menjadikan bakteri lebih bersifat hidrofobik (Rosenberg dan Doyle, 1990).

\section{Kesimpulan}

Berdasarkan hasil penelitian dapat disimpulkan bahwa aktivitas virulensi $\quad \mathrm{S}$. aureus isolat preputium sapi Aceh berdasarkan karaksteristik hidrofobisitas tergolong positif moderat, yaitu $36,76 \%$. Aktivitas antibiotik dapat mempengaruhi hidrofobisitas S. aureus. Tetrasiklin $30 \% \quad(\mathrm{mg} / \mathrm{mL}) \quad$ mempunyai kemampuan paling baik meningkatkan hidrofobisitas S. aureus sebesar $36,16 \%$ menjadi $72,29 \%$. Sehingga aktivitas virulensi S. aureus isolat preputium sapi Aceh menjadi lemah atau tergolong positif palsu.

Penelitian lanjutan perlu dilakukan terkait aktivitas antibiotik terhadap aktivitas virulensi S. aureus isolat preputium sapi Aceh berdasarkan karaksteristik lain seperti phospolipase dan proteinase dengan menggunakan antibiotik dengan konsentrasi lain yang berbeda. Selanjutnya perlu juga dilakukan analisa secara molekuler untuk melihat ekspresi gen $\mathrm{S}$. aureus isolat preputium sapi Aceh, terkait resistensinya terhadap antibiotik.

\section{Daftar Pustaka}

Toriyama, Y. Tanimoto, S. Sugiyama, Singgle crystalline silicon nano wire piezoresistors for mechanical sensors, Transducers '01 Eurosensors XV Digest of technical papers, Munich (2001), p. 1002-1005.

Das, S.C. \& K.N. Kapoor. (2004). Efect of growth medium on hydrophobicity of Staphylococcus epidermidis. Indian Journal. Med. Res. (119): 107 - 109.

Fardiaz, D., \& L.E. Radiati. 2012. Pengaruh Whey Kefir Susu Kambing Terhadap Hidrofobisitas Bakteri E. Coli O157:H7, S. Typhi. Jurnal Ilmu dan Teknologi. Vol. 7(1): 12-18.

Jawetz, Melnick, \& Adelbergs. 2005. Mikrobiologi Kedokteran. Salemba Medika, Jakarta.

Lee, K.K. \& K.C. Yii. 1996. A Comparison of three methods for assaying hydrophobicity of pathogenic vibrios. Journal. Letters In Appl. Microbiol. 13: 343-346.

Lestari, F. B., \& Siti, I.O.S. 2015. Karakterisasi Staphylococcus aureus Isolat Susu Sapi Perah Berdasarkan Keberadaan Protein-A pada Media Serum Soft Agar terhadap Aktivitas Fagositosis Secara Invitro. Journal Sain Veteriner 33 (20): 149-155.

Plata, K., A.E. Rosato, \& G. Wegrzyn. 2009. Staphylococcus aureus as an infectious agent: overview of biochemistry and molecular genetics of its pathogenicity. Journal. Acta Biochim. 56 (4): 597-612.

Rosenberg, E. \& R.J. Doyle. 1990. Microbial cell surface hydrophobicity: History, meansurement and significance. In Doyle R.J. and M. Rosenberg. Eds. Microbial Cell Surface Hydrophobicity. American Society for Microbiology. Washington. D.C.

Salasia, S.I.O., M.H. Wibowo, \& Khusnan. 2005. Karakterisasi fenotipe Staphylococcus aureus isolat dari sampel susu sapi perah mastitis sub klinis. Jurnal Sain Veteriner. 23:72-78. 